\title{
EDITORIAL
}

\section{Childhood asthma in the Year of the Lung}

\author{
K-H. Carlsen*\#, G. Hedlin ${ }^{\star}$ and A. Bush ${ }^{+}$
}

$\mathbf{P}$ aediatric asthma may be named "the illness of our time". It is as complex as the life of our time; it has increased in occurrence over the last 50 to 60 years to become the most common illness of childhood and adolescence and, despite the very extensive efforts to try to find out the cause of this increase, we must be honest and say that we do not know. Asthma has both a chronic and an acute presentation, causing reduced quality of life in many children and their families [1].

The chief editors of the European Respiratory Journal (ERJ) have decided that in the Year of the Lung, we should have a series of articles on paediatric asthma, outlining the many different faces of this disease and to tell something of the story of the venture into the attempts to solve the many questions of paediatric asthma. Through this series we will try to highlight the many faces of paediatric asthma, focusing on severe asthma, the role of virus, allergies and exercise for the many clinical presentations of asthma. One article will give an update on epigenetics and asthma.

Modern asthma treatment improves quality of life in most children with asthma; however, some asthmatic children do not respond to asthma treatment and, in particular, not to inhaled corticosteroids. Two articles will appear related to problematic severe asthma in children [2]. The first is entitled "Problematic severe asthma in children, not one problem but many: a GA $^{2}$ LEN initiative" [3] and refers to a group of European paediatricians working together to define and describe the phenotypes and the clinical presentation of severe problematic asthma: the PSACI (Problematic Severe Asthma in Childhood Initiative) group. Additionally, an article on problematic severe asthma from this group will appear and focus on diagnostic criteria and treatment. Furthermore, H. de Groot and coworkers will review co-morbidities of asthma during childhood and adolescence [4]. They will include not only the atopic comorbidities, such as allergic rhinitis, but also accompanying problems, such as anxiety, depression and obesity.

Respiratory virus infections are the most common cause of acute asthma exacerbations [5]. Additionally, it is debated if rhinovirus infections, in particular, are involved in the pathogenesis of asthma in young children [6]. Highly relevant to these topics, the second article of the series, to appear in a

\footnotetext{
*Dept of Paediatrics, Oslo University Hospital, and "Faculty of Medicine, University of Oslo, Oslo, Norway. `Astrid Lindgren Children's Hospital Q2:05, Karolinska University Hospital and Centre for Allergy Research, Karolinska Institutet, Stockholm, Sweden. ${ }^{+}$Dept of Respiratory Paediatrics, Royal Brompton Hospital, London, UK.
}

CORRESPONDENCE: K-H. Carlsen, Dept of Paediatrics, Oslo University Hospital, University of Oslo, Voksentoppen, Oslo, N0 0027, Norway. E-mail: k.h.carlsen@medisin.uio.no following issue of the ERJ, will cover the present knowledge with regards to asthma and respiratory virus infections and the relationship between respiratory virus infections and acute asthma exacerbations.

Asthma genetics has been a major focus of asthma research over the last decade. Confusingly, the results of studies on the role of different single nucleotide polymorphisms have largely not been reproducible and have varied in different geographical locations. Environmental influences may directly impact on gene expression through the epigenetic mechanisms [7]. The effect of DNA methylation has been most studied and has been shown to have a direct effect upon gene activity. M. Kabesch will discuss epigenetic mechanisms and the relationship to childhood asthma.

There is ongoing controversy about the role of allergy in childhood bronchial asthma. Is allergy a major factor for developing asthma? Or is asthma an epithelial disease? This will be discussed further in one article posing the question "Is asthma still an allergic disease?"

Finally, the extraordinary feature of asthma that physical activity provokes bronchial obstruction and the important phenotype of exercise-induced asthma will be the topic of one article concerning the breathless adolescent athlete. This is a complex issue, because physical activity improves quality of life in children and adolescents with asthma [8]; however, it causes exacerbations of asthma [9] and may initiate asthma in previous healthy adolescent athletes [10].

Thus, starting with the present issue of the ERJ, readers can look forward to a series of articles on childhood asthma, bringing novel and up to date information about asthma from the clinical perspective as well as from the front line in basic and translational research.

\section{STATEMENT OF INTEREST}

Statements of interest for K-H. Carlsen and A. Bush can be found at www.erj.ersjournals.com/misc/statements.dtl

\section{REFERENCES}

1 Strunk RC, Mrazek DA, Fuhrmann GS, et al. Physiologic and psychological characteristics associated with deaths due to asthma in childhood. A case-controlled study. JAMA 1985; 254: 1193-1198.

2 Bush A, Hedlin G, Carlsen KH, et al. Severe childhood asthma: a common international approach? Lancet 2008; 372: 1019-1021.

3 Hedlin G, Bush A, Lødrup Carlsen K, et al. Problematic severe asthma in children, not one problem but many: a GA ${ }^{2} L E N$ initiative. Eur Respir J 2010; 36: 196-201.

4 Corren J. Allergic rhinitis and asthma: how important is the link? J Allergy Clin Immunol 1997; 99: S781-S786. 
5 Johnston SL, Pattemore PK, Sanderson G, et al. Community study of viral infections in exacerbations of asthma in 9-11 year old children. BMJ 1995; 310: 1225-1229.

6 Lemanske RF Jr, Jackson DJ, Gangnon RE, et al. Rhinovirus illnesses during infancy predict subsequent childhood wheezing. J Allergy Clin Immunol 2005; 116: 571-577.

7 Miller RL, Ho SM. Environmental epigenetics and asthma: current concepts and call for studies. Am J Respir Crit Care Med 2008; 177: 567-573.

8 Ram FS, Robinson SM, Black PN. Effects of physical training in asthma: a systematic review. Br J Sports Med 2000; 34: 162-167.
9 Anderson SD, Barnes PJ, Roger IW, et al. Exercise-induced asthma: Stimulus, mechanism and management. In: Barnes PJ, Rodger IW, Thomson NC, eds. Asthma: Basic Mechanisms and Clinical Management. London, Academic Press; 1988. pp. 503-522.

10 Carlsen KH, Anderson SD, Bjermer L, et al. Exercise-induced asthma, respiratory and allergic disorders in elite athletes: epidemiology, mechanisms and diagnosis: part I of the report from the Joint Task Force of the European Respiratory Society (ERS) and the European Academy of Allergy and Clinical Immunology (EAACI) in cooperation with $\mathrm{GA}^{2} \mathrm{LEN}$. Allergy 2008; 63: 387-403. 